Article

\title{
Gasification of a Dried Sewage Sludge in a Laboratory Scale Fixed Bed Reactor
}

\section{Sebastian Werle}

Institute of Thermal Technology, Silesian University of Technology, Konarskiego 22, 44100 Gliwice, Poland; E-Mail: sebastian.werle@polsl.pl; Tel.: +48-322-372-983; Fax: +48-322-372-872

Academic Editor: Shusheng Pang

Received: 17 June 2015 / Accepted: 23 July 2015 / Published: 12 August 2015

\begin{abstract}
This paper presents an investigation of sewage sludge gasification in a fixed bed gasifier. Experiments were conducted on a laboratory scale fixed bed gasifier. In the experiments, two types of dried sewage sludge were tested and their properties were analysed. Parameters such as air ratio $\lambda=0.12$ to 0.27 , gasification agent temperature $\mathrm{t}=50$ to $250{ }^{\circ} \mathrm{C}$ and gasification agent composition $\left(z_{\mathrm{O}_{2}}=0.21\right.$ and $\left.z_{\mathrm{O}_{2}}>0.21\right)$ were found to influence on temperature distribution, syngas Lower Heating Value (LHV) and syngas composition. The results indicate that the syngas LHV was found to decrease with increased air ratio for all analyzed cases: cold and preheated air and cold enriched air. The increase in the percentage of the main combustible components was accompanied by a decrease in the concentration of carbon dioxide. Increasing oxygen concentration increased the temperature, which tended to favor the formation of smaller molecules in the gas mixture. Thus, the enriched air medium produced a gas with a higher LHV. In contrast to conventional gasification, gasification process with gasification agent preheating causes that the flux of heat necessary to support endothermic gasification reactions is producing more effective. Air preheating causes increases hydrogen and carbon monoxide production.
\end{abstract}

Keywords: sewage sludge; gasification; syngas; operating parameters; fixed bed installation

\section{Introduction}

Significant increases in the amount of sewage sludge has become a common environmental problem globally. Thus, the need for a proper waste management strategy is inevitable as it is a vital part of sustainability and environmental protection [1]. An appropriate approach should minimize the amount 
of sewage sludge and maximize its recovery to useful utilization [2]. On an international level, proper sewage sludge management — as one means for mitigating carbon emission — is well recognized in the Kyoto Protocol. In terms of climate change policy, the Kyoto Protocol is considered to be the most crucial driver for the utilization and diffusion of waste-to-energy (WTE) technology [3]. The thermo-chemical conversion of sewage sludge consists of four main processes: combustion, co-combustion, pyrolysis and gasification. One of the promising thermo-chemical conversion technologies that can be used to convert sewage sludge to useful energy forms suited for small to medium size throughput is gasification [4]. Depending upon the gasifying medium used the gasifiers are basically classified as oxygen, steam or air blown gasifiers. The gasification process proceeds in four steps viz. drying, pyrolysis, oxidation (combustion) and reduction (char gasification). In a typical gasifier drying occurs at a temperature of less than $150{ }^{\circ} \mathrm{C}$, pyrolysis occurs in the temperature range of $150-700{ }^{\circ} \mathrm{C}$, oxidation occurs in the range of $700-1500{ }^{\circ} \mathrm{C}$ and reduction occurs in the range of $800-1100{ }^{\circ} \mathrm{C}$ [5]. Gasification takes places in gasifiers. They are categorized as (a) fixed bed (also known as moving bed), (b) fluidized bed and (c) entrained flow gasifiers depending upon how the gas and fuel contact each other [5]. Depending upon the pressure used the reactors are classified as atmospheric or pressurised. Also, if the reactors are heated by an external source, then they are known as allothermal or indirectly heated reactors and if the heat is provided by the partial combustion of feedstock they are known as auto-thermal or directly heated reactors [5].

Gasification converts the materials into a gas by creating a chemical reaction. This reaction combines those carbon-based materials (known as the feedstock) with small amounts of air or oxygen, breaking them down into simple molecules, primarily a mixture of carbon monoxide and hydrogen, and removing pollutants and impurities. What's left is a clean "synthesis gas" (syngas) that can be converted into electricity and other valuable products. It can be combusted or co-combusted in power boilers, industrial furnaces, combustion engines and gas turbines. The fact that gasification occurs at a much smaller oxygen level than is the case of combustion processes should be first and foremost taken into account. Therefore, the quantity of gaseous products (particularly oxides) is smaller, and the gas cleaning system may be much less extensive. Previous studies [6] have shown that the gasification of sewage sludge in fixed bed reactors (and the downdraft version of these reactors) produce a gas with a relatively low tar content because of the decomposition and oxidation of the tar products that pass through the high-temperature combustion zone during gasification. Encouraging studies on sewage sludge gasification in a pilot-scale updraft fixed-bed gasifier have been reported by Seggiani et al. [7]. Results on sewage sludge gasification in a laboratory scale downdraft have been reported by many researchers [8-10]. Werther et al. [11] and Nilsson et al. [12] have carried out gasification experiments with sewage sludge in fluidized beds.

Performance produced gas composition of a gasification process is dependent upon the feedstock characteristics, the reactor design and the operating parameters [13]. Feedstock characteristics that have been found to have major influence on the gasification process are moisture content, volatile matter, ash content, char and thermal conductivity [13]. Sewage as a fuel is characterized by completely different properties in comparison to conventional biomass. It is observed that sewage sludge feedstocks tend to have less volatile components (approximately 50\% on a dry basis) than biomass (around 70\%) [14]. Due to this fact, gasification of sewage sludge (in contrast to other forms of solid biomass, such as wood, agricultural wastes, and energy crops) is still insufficiently explored. 
Conducting scientific and development research in this field is still valid. This makes that the research, on which this paper focuses, becomes important. This article reports on a multi-parameter analysis of the sewage sludge fixed-bed gasification process.

\section{Experimental}

\subsection{Apparatus}

A scheme of the fixed bed gasification facility is shown in Figure 1 [15]. The main system component was a stainless gasifier, with a $150 \mathrm{~mm}$ internal diameter and a total height of $300 \mathrm{~mm}$. The reactor was well insulated to prevent major heat losses. Granulated sewage sludge from the container was fed into the reactor. After approximately $120 \mathrm{~min}$, the reactor was heated. The gasification cold air and preheated air flow rate/enriched air flow rate to the reactor was adjusted to ensure a specified air ratio. Once producer gas production began, the measurements of key parameters were started. As the sewage sludge was gasified, the ash produced was gradually discharged from the bed. The bed was maintained at a constant height by the addition of fuel at regular time intervals. A fraction of the gases produced during gasification was first passed through a condensing system which condensed out the condensable, followed by a set of filters for particulate removal to allow clean gas to enter the gas analyzer. The aim of the particle measurement systems was to extract a sample of the hot product gas, without changing the size distribution and composition of the Particulate Matter (PM), to allow PM characterization using various instruments and analysis techniques. Representative gas samples were also collected in Tedlar ${ }^{\odot}$ gas bags for off-line measurements. The gases were subsequently analyzed using a gas chromatograph Agilent $6980 \mathrm{~N}$ series. The same procedure was repeated at different air ratios. Uncertainty in the measurements might have arisen from errors in the mass balances and volumetric apparatuses. In this experiment, all parameters were measured by appropriately calibrated laboratory equipment. The gasification agent flow rate and the syngas flow rate were measured by flow meters. The syngas was transported from the gasifier by a pipe. The syngas was cleaned by a cyclone, a scrubber and a drop separator.

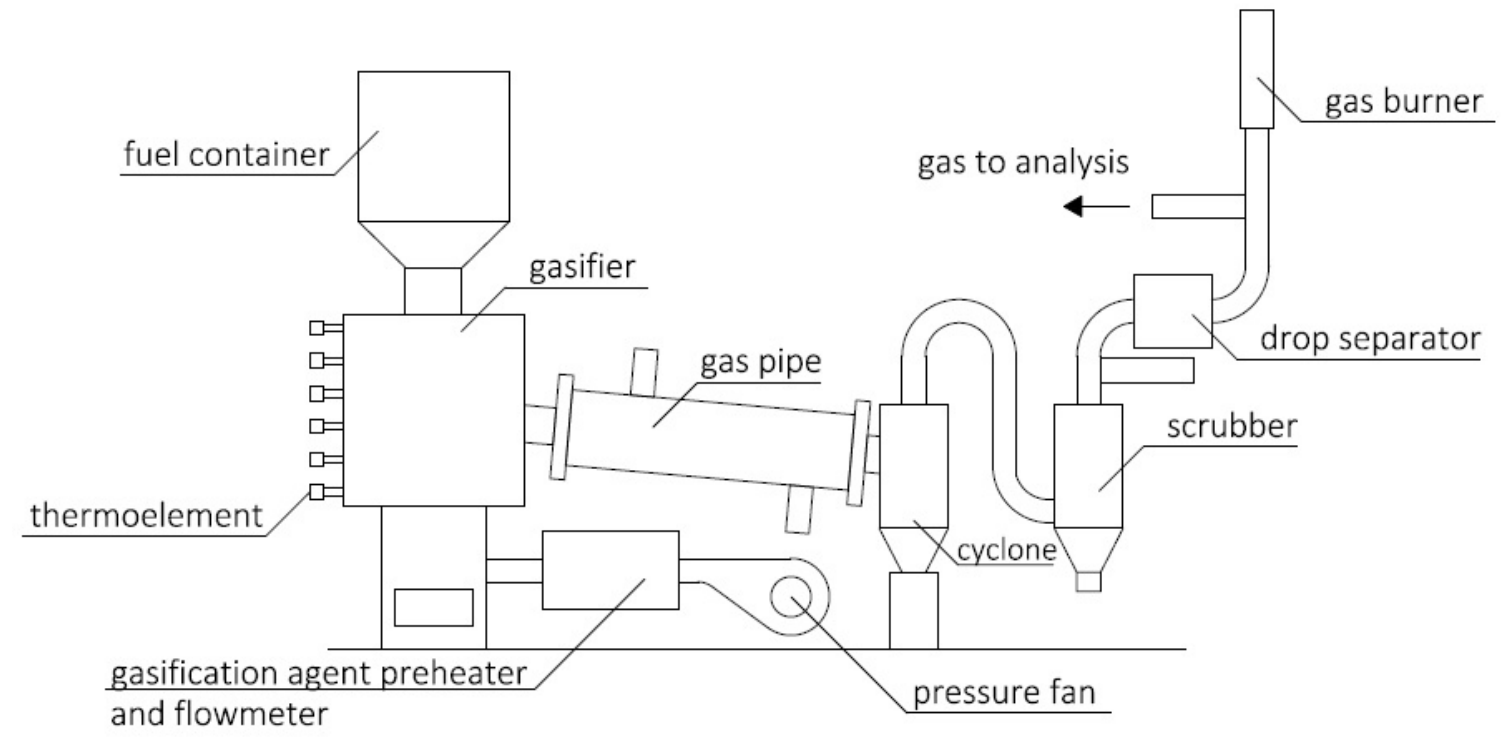

Figure 1. Scheme of the experimental system. 


\subsection{Fuel Properties}

In the experiments, two types of dried sewage sludge were tested and their properties were analysed. Sewage sludge No. 1 (SS1) was taken from a wastewater treatment plant operating in the mechanical-biological system and sewage sludge No. 2 (SS2) was taken from mechanical-biological-chemical wastewater treatment plant with phosphorus precipitation. In both analyzed cases, the biological part of the wastewater treatment plant has worked with low load activated sludge. Thanks to it, effective removal of nutrients (phosphorus and nitrogen) from wastewaters is allowed. Additionally, in both analyzed cases, sewage sludge is stabilized by anaerobic digestion and dewatering. After it, sewage sludge is dried. In the case 1 (SS1), sewage sludge was dried in cylindrical dryer with a heated shelf. The temperature of hot air was equal to $260{ }^{\circ} \mathrm{C}$ (high temperature). In the case 2 (SS2), an air belt dryer was used. The temperature of hot air in this case was equal to $150{ }^{\circ} \mathrm{C}$ (low temperature). As a result, sludge SS1 had a granular form of, while sludge SS2 was in the shape of irregular thin "pasta" (Figure 2).

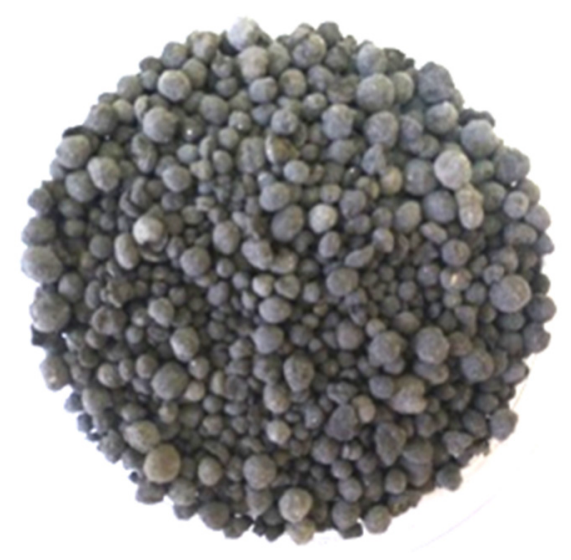

(a)

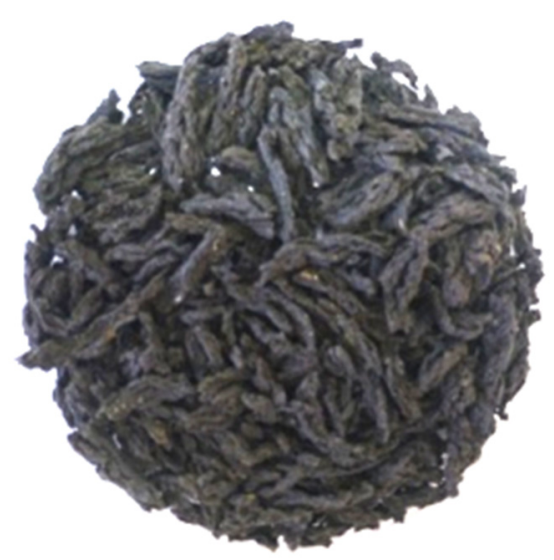

(b)

Figure 2. Sewage sludge analyzed: (a) SS1; (b) SS2.

The qualitative chemical analysis of the dried sewage sludge and waste by-products produced during gasification covered the concentrations of major elements (carbon, hydrogen, nitrogen, chlorine, fluorine, sulphur and oxygen) and selected heavy metals (zinc, selenium, lead, nickel, mercury, copper, chromium, cadmium, arsenic). The concentrations of the major elements were assayed using automatic measurements with an IR analyzer. The heavy metals were determined by plasma or absorption spectrometry. The assays carried out in the liquid products covered: total organic carbon using an automatic analyzer and ammonia nitrogen concentration (spectrophotometer).

The authors of earlier works in this field [16] assayed moisture, volatile fractions, ash, heat of combustion and their calorific value as well. As for the ash, indicators characteristic of its tendency towards slagging and fouling of heated surfaces as well as agglomerate formation were determined. The assays of moisture, volatile fractions and ash were conducted with the gravimetric methods given in the following standards PN-EN 14774-3:2010 [17], PN-EN 15402:2011 [18] and PN-EN 15403:2011 [19], respectively. The higher heating value was determined by the calorimetric method while the lower calorific value was calculated, using the mass fractions of the major elements in a sample. The characteristics of the two sewage sludges are given in Table 1. 
Table 1. Properties of the fuel tested.

\begin{tabular}{|c|c|c|}
\hline \multirow{2}{*}{ Element/Parameter } & \multicolumn{2}{|c|}{ Sewage Sludge } \\
\hline & SS1 & SS2 \\
\hline Proximate Analysis & \multicolumn{2}{|c|}{$\%$ (as received) } \\
\hline Moisture & 5.30 & 5.30 \\
\hline Volatile matter & 51.00 & 49.00 \\
\hline Ash & 36.50 & 44.20 \\
\hline Ultimate Analysis & \multicolumn{2}{|c|}{$\%$ (dry basis) } \\
\hline $\mathrm{C}$ & 31.79 & 27.72 \\
\hline $\mathrm{H}$ & 4.36 & 3.81 \\
\hline $\mathrm{N}$ & 4.88 & 3.59 \\
\hline O (by difference) & 20.57 & 18.84 \\
\hline $\mathrm{S}$ & 1.67 & 1.81 \\
\hline $\mathrm{F}$ & 0.013 & 0.003 \\
\hline $\mathrm{Cl}$ & 0.22 & 0.03 \\
\hline \multicolumn{3}{|l|}{ Calorific Value } \\
\hline Higher heating value (HHV), $\mathrm{MJ} / \mathrm{kg}$ dry basis & 14.05 & 11.71 \\
\hline Lower heating value (LHV), MJ/kg dry basis & 12.96 & 10.75 \\
\hline
\end{tabular}

In order to identify any potentially dangerous substances existing in the sludge a chemical analysis has been done (Table 2). Among other organic compounds, Polycyclic aromatic hydrocarbons (PAHs) in the sludge have been determined. SS1 contained nine (phenanthrene, anthracene, benzo(a)fluoranthene, pyrene, chrysene, benzo(b)- fluoranthene, dibenzo(a,h)anthracene, benzo(g,h,i)perylene, indeno(1,2,3-cd)pyrene), while SS2 had eight (acenaphthene, benzo(a)fluoranthene, pyrene, benzo(a)anthracene, chrysene, benzo(b)fluoranthene, benzo(a)pyrene, indeno(1,2,3-cd)pyrene) compounds from that group of contaminants (naphthalene, acenaphthylene, acenaphthene, fluorene, phenanthrene, anthracene, benzo(a)fluoranthene, pyrene, benzo(a)anthracene, chrysene, benzo(b)fluoranthene, benzo(k)fluoranthene, benzo(a)pyrene, dibenzo(a,h)anthracene, benzo(g,h,i)perylene, indeno(1,2,3-cd)pyrene). The total concentration of PAHs (Table 2) was four times higher in SS1 than in SS2. This was mainly connected with the origin of the sludge. SS2 is taken from a wastewater treatment plant operating in the mechanical-biological-chemical system. Organic impurities from the sludge were removed in the third stage of the system.

The organic contaminants identified in the sewage sludge also included pesticides and polychlorinated biphenyls. It is worth mentioning that SS1 revealed the presence of three pesticides (heptachlor, aldrin, endrin) from the group of those commonly found in the natural environment in Poland (heptachlor, hexachlorocyclohexane, heptachlor epoxide, aldrin, endrin) [20]. Like the group of polycyclic aromatic hydrocarbons, the total concentrations of pesticides and polychlorinated biphenyls (PCBs) were higher in SS1 than SS2. The heavy metal content analysis shows that their total concentration in the sludge is similar in both cases: $1841.19 \mathrm{mg} / \mathrm{kg}$ for SS1 and $1847.6 \mathrm{mg} / \mathrm{kg}$ for SS2. Big differences have been noted in the chromium concentrations of the analyzed sludges, as the Cr concentration in the case of the SS2 was three times higher in comparison to sludge SS1. 
Table 2. Concentration of organic and inorganic compounds in sewage sludge.

\begin{tabular}{|c|c|c|}
\hline \multirow{2}{*}{ Compound } & \multicolumn{2}{|c|}{ Sewage Sludge } \\
\hline & SS1 & SS2 \\
\hline Polycyclic aromatic hydrocarbons (PAHs) & \multicolumn{2}{|c|}{ Concentration, $\mu \mathrm{g} / \mathrm{kg}$ dry basis } \\
\hline acenaphthene & n.d. & 80.84 \\
\hline phenanthrene & 511.12 & n.d. \\
\hline anthracene & 200.03 & n.d. \\
\hline benzo(a)fluoranthene & 44.78 & 126.48 \\
\hline pyrene & 187.22 & 123.86 \\
\hline benzo(a)anthracene & n.d. & 35.15 \\
\hline chrysene & 108.14 & 23.79 \\
\hline benzo(b)fluoranthene & 700.51 & 53.62 \\
\hline benzo(a)pyrene & n.d. & 46.11 \\
\hline dibenzo(a,h)anthracene & 101.54 & n.d. \\
\hline benzo(g,h,i)perylene & 209.44 & n.d. \\
\hline indeno( $1,2,3-\mathrm{cd})$ pyrene & 370.62 & 131.48 \\
\hline Sum & 2433.40 & 621.33 \\
\hline Pesticides & \multicolumn{2}{|c|}{ Concentration, $\mu \mathrm{g} / \mathrm{kg}$ dry basis } \\
\hline heptachlor & 4.14 & n.d. \\
\hline aldrin & 3.13 & 1.28 \\
\hline endrin & 11.58 & n.d. \\
\hline Sum & 18.85 & 1.28 \\
\hline pesticides and polychlorinated biphenyls (PCBs) & \multicolumn{2}{|c|}{ Concentration, $\mu \mathrm{g} / \mathrm{kg}$ dry basis } \\
\hline $2,2^{\prime}, 5,5^{\prime}-\mathrm{PCB}$ & 9.75 & 7.90 \\
\hline $2,2^{\prime}, 4,5,5^{\prime}-\mathrm{PCB}$ & 33.33 & n.d. \\
\hline $2,2^{\prime}, 4,4^{\prime}, 5,5^{\prime}-\mathrm{PCB}$ & 23.78 & 4.57 \\
\hline Sum & 66.86 & 12.47 \\
\hline Heavy metals & \multicolumn{2}{|c|}{ Concentration, $\mathrm{mg} / \mathrm{kg}$ dry basis } \\
\hline $\mathrm{Zn}$ & 920.90 & 991.20 \\
\hline $\mathrm{Cu}$ & 495.30 & 183.16 \\
\hline $\mathrm{Pb}$ & 119.30 & 59.97 \\
\hline $\mathrm{Ni}$ & 103.67 & 18.90 \\
\hline $\mathrm{Cr}$ & 180.53 & 584.53 \\
\hline $\mathrm{Cd}$ & 6.47 & 3.24 \\
\hline As & 4.19 & 3.94 \\
\hline $\mathrm{Hg}$ & 0.99 & 0.96 \\
\hline $\mathrm{Se}$ & 9.84 & 1.70 \\
\hline Sum & 1841.19 & 1847.6 \\
\hline
\end{tabular}

n.d.: Not detected.

\section{Results and Discussion}

\subsection{Influence of the Air Ratio on the Syngas Composition}

Figure 3 shows the evolution of the $\mathrm{H}_{2}, \mathrm{CO}, \mathrm{CO}_{2}$ and $\mathrm{CH}_{4}$ concentrations in gasification gas with varying air ratios for both analyzed sludges. Air ratio is a parameter that quantifies the amount of 
air/oxygen per unit mass of fuel, as compared to the theoretical amount of air/oxygen needed for complete combustion. This parameter is quite often used in Europe in comparison to equivalence ratio, as a reverse of the air ratio, which is most often used in the US. Hence the optimum air ratio that favors gasification (incomplete combustion) resulting in combustible gases like $\mathrm{CO}$, rather than the case of complete combustion with an air supply that mainly produces $\mathrm{CO}_{2}$ need to be determined. In this study a number of gasification experiments were done by varying the air ratio from 0.12 to 0.27 .

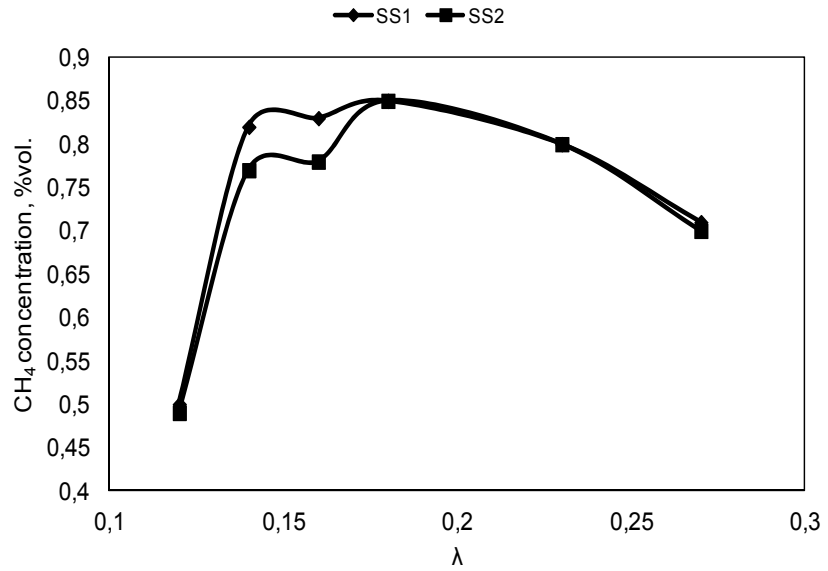

(a)

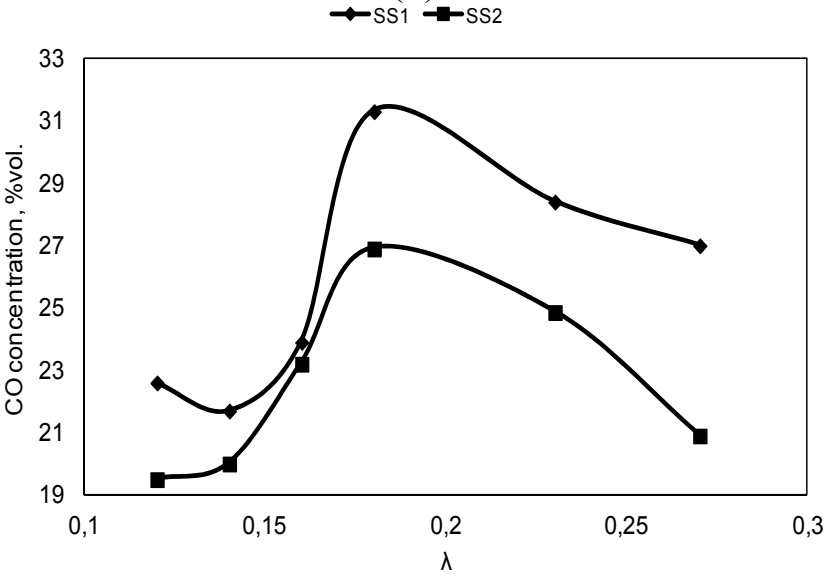

(c)

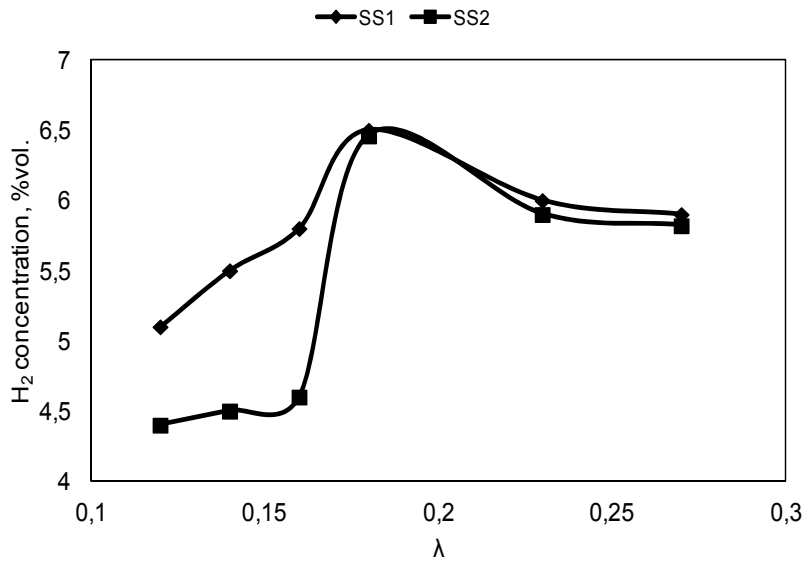

(b)

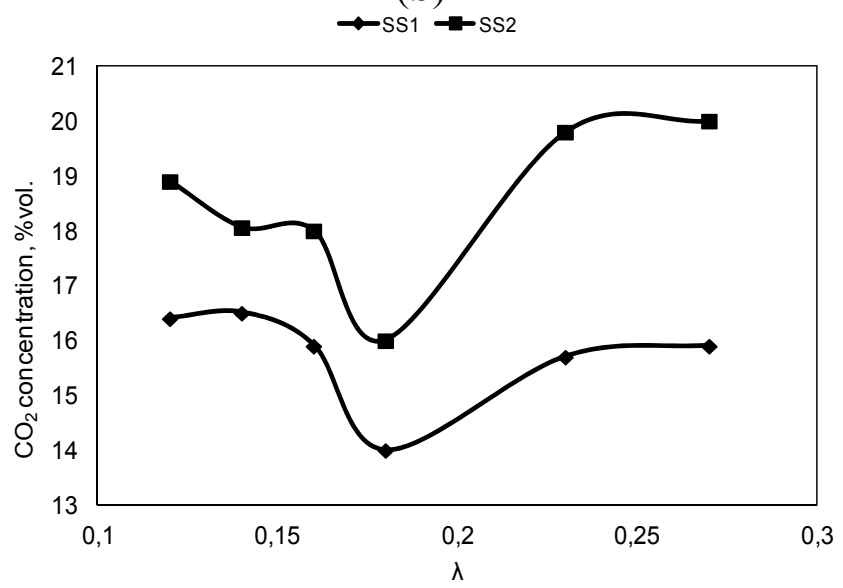

(d)

Figure 3. Evolution of the main components in sewage sludge gasification gas as a function of the air ratio: (a) methane; (b) hydrogen; (c) carbon monoxide; (d) carbon dioxide.

Analyzing this figure it can be confirmed that throughout the range of analyzed air ratio volumetric fraction of main combustible components of gasification gas $\left(\mathrm{CO}\right.$ and $\left.\mathrm{H}_{2}\right)$ are higher in the case of the SS1 (positive aspect) in comparison to SS2. At lower air ratio values, CO composition was found to be low and it starts to rise to the optimum air ratio of 0.18 and later drops for higher air ratios. The maximum CO average composition values of 31.3\% for SS1 (and 26.9\% for SS2) were obtained for gasification at $\lambda=0.18 . \mathrm{CO}_{2}$ shows an inverse relation with $\mathrm{CO}$ as the reactions that produce those gases are competing for the same reactant, namely carbon. The concentration of carbon dioxide is generally expected to be the smallest of the optimal air ratio range between 0.18-0.24. Rapid growth of $\mathrm{CO}$ observed in the value of the air ratio equal to 0.18 is caused by the dominant role of the primary water gas reaction. The reactions that can occur in the gasifier as a result of the gasification agent flow 
can be categorized as the reaction of gasification agent and carbon in the fuel and the reaction of gasification agent and $\mathrm{CO}$ in the gas. The reaction of gasification air and carbon is an endothermic process that generates mainly $\mathrm{CO}$, whereas the reaction of gasification air and $\mathrm{CO}$ is an exothermic one, that generates mainly $\mathrm{CO}_{2}$ (and $\mathrm{H}_{2}$ ). When gasification air is fed with the fuel into the reactor, the endothermic reaction of air and carbon occurs first (e.g., primary water gas reaction $\mathrm{CO}+\mathrm{H}_{2} \mathrm{O} \rightarrow \mathrm{CO}+\mathrm{H}_{2}$ ), and the $\mathrm{CO}$ in a gaseous state produced from the fuel reacts with the residuals causing next reactions (e.g., water gas shift $\mathrm{CO}+\mathrm{H}_{2} \mathrm{O} \leftrightarrow \mathrm{CO}_{2}+\mathrm{H}_{2}$ ). Thus, the composition of $\mathrm{H}_{2}, \mathrm{CO}$ and $\mathrm{CO}_{2}$ in the gasification gas changes according to the amount of the air supplied to the reactor.

On the Figure 4 there is presented dependence of the lower heating value (LHV) of obtaining gas versus an air ratio. The lower heating value (LHV) in $\mathrm{MJ} / \mathrm{m}^{3}$ of the syngas was estimated using the formula given below [21]:

$$
\mathrm{LHV}=0.126 \cdot \mathrm{CO}+0.108 \cdot \mathrm{H}_{2}+0.358 \cdot \mathrm{CH}_{4}
$$

Analyzing Figure 4, it can be concluded that taking into consideration the lower heating value LHV of the gasification gas there is the optimum value of the air ratio equal to 0.18 in which the LHV adopts its maximum value. It is true irrespective of the sewage sludge type. Above that optimal value, the thermochemical process could be shifted from gasification to combustion.

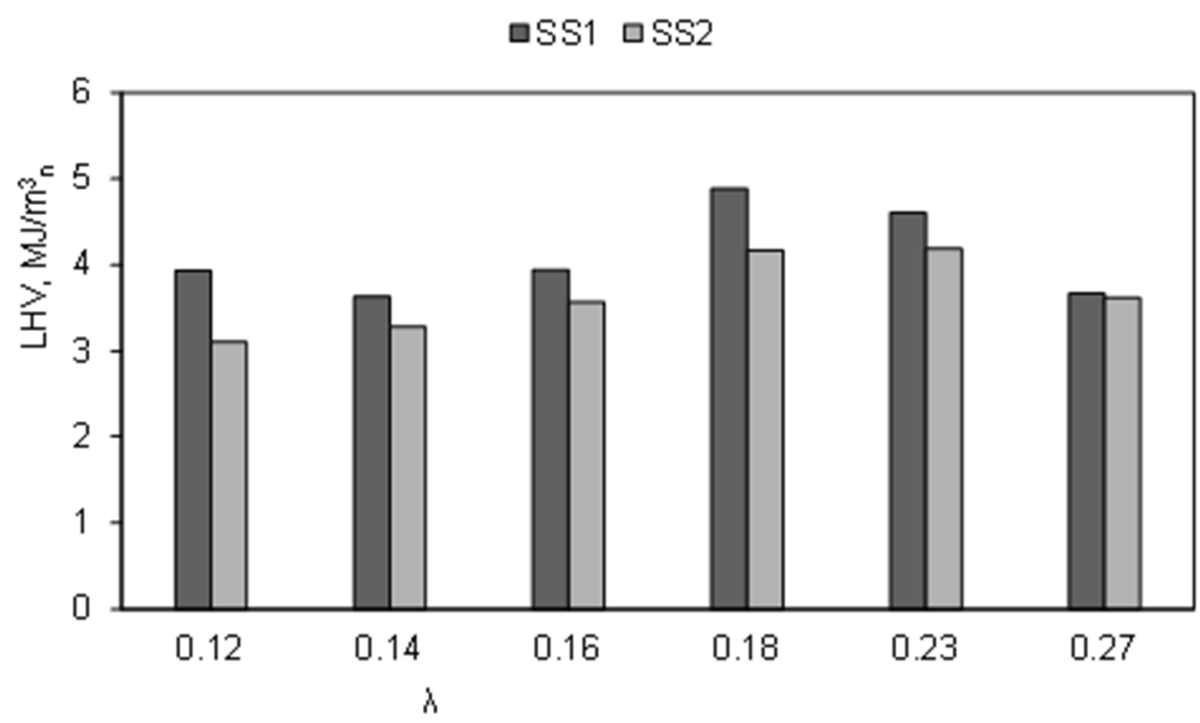

Figure 4. Lower heating value (LHV) of the gasification gas versus air ratio.

\subsection{Influence of the Temperature of Gasification Agent on Syngas Composition}

Figure 5 demonstrates that the use of hot air for sewage sludge gasification was able to produce gasification gas with a superior heating value compared to low temperature gasifiers, which produce producer gas with LHVs ranging up $5.12 \mathrm{MJ} / \mathrm{m}^{3}$. It is caused by the increment of the yield of the main producer gas components, $\mathrm{CO}, \mathrm{H}_{2}$ and $\mathrm{CH}_{4}$, which were enhanced by increasing the gasification agent temperature. This is mainly due to the endothermic reactions involved in the gasification process which become more dominant at higher temperatures. Similar behavior is also found during catalytic gasification. The high temperature of gasification agent was sufficient to allow for secondary thermocracking reactions that increased the producer gas yield. 


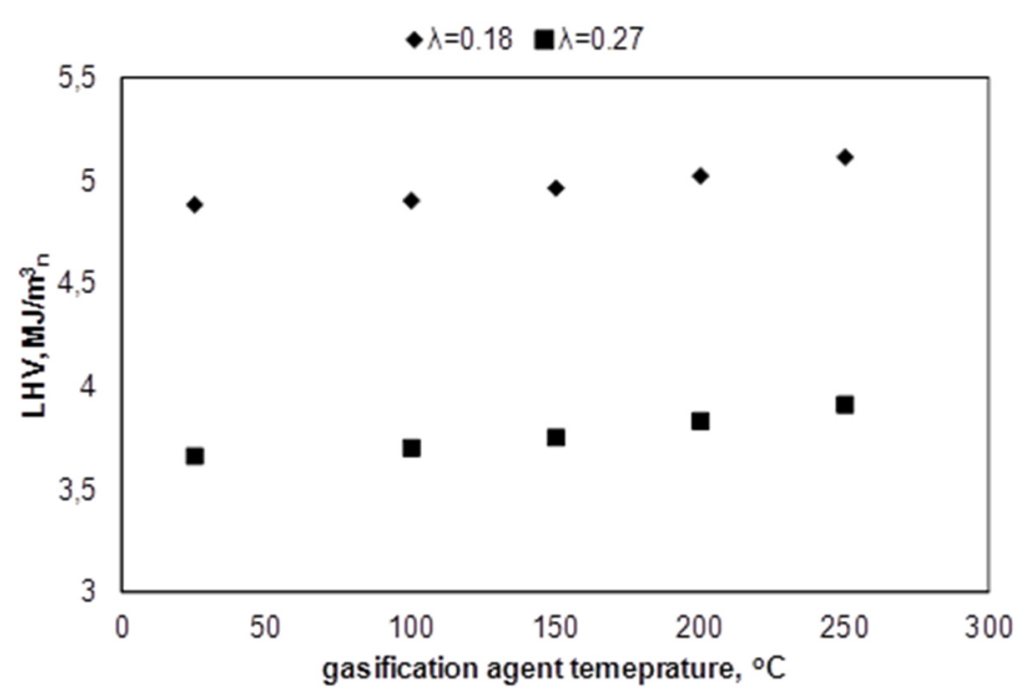

Figure 5. Influence of the gasification agent temperature on the LHV of the syngas.

\subsection{Influence of the Gasification Agent Composition on Syngas Composition}

Figure 6 shows the influence of the gasification agent composition on the LHV of producing gas. The gasification agent studied is composed of nitrogen and oxygen mixtures. The oxygen molar concentration studied was equal to: $21 \%$ and $25 \%$.

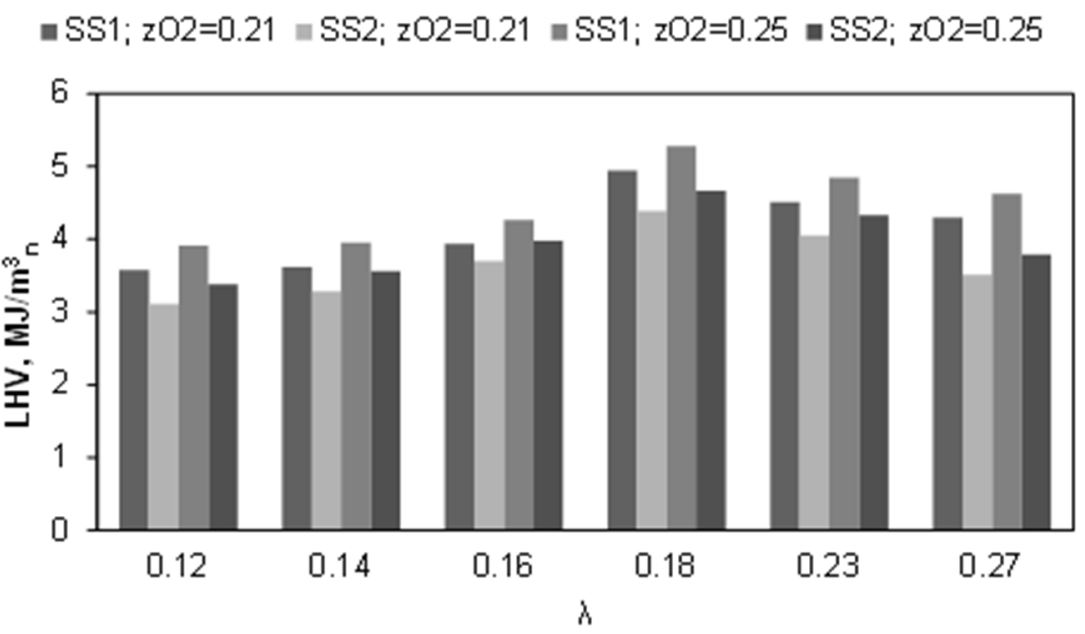

Figure 6. Influence of the gasification composition on the syngas LHV.

Analyzing the results presented in Figure 6 it can be concluded that the LHV of the producer gas increased slightly with the increment of the oxygen concentration in the gasification agent. This is mainly caused by the lower dilution by the nitrogen.

The whole system was also analyzed taking into consideration the energy efficiency. Two parameters were calculated. Cold Gas Efficiency (CGE) was calculated as the chemical enthalpy of the syngas calculated on the basis of its composition related to the chemical enthalpy of the gasified biomass, while Hot Gas Efficiency (HGE) was the total enthalpy of the syngas related to the chemical enthalpy of the biomass. These values vary between $51.2 \%-58.8 \%$ in the case of the CGE, and $55.6 \%-67.9 \%$ in the case of HGE. 


\section{Conclusions}

The main conclusions from the study are as follows: (i) Original experimental results on sewage sludge gasification are presented in this study. Air/enriched air gasification of sewage sludge was investigated, and a fixed bed reactor was used. Such experiments have not been previously conducted on Polish sewage sludge used as a feedstock in the gasification process. The results obtained showed that gasification of sewage sludge in a fixed bed gasification installation is technically feasible. (ii) Sewage sludge has a high and worldwide economic potential due to its extremely low price. (iii) The operating conditions (amount of the gasification agent) of the sewage sludge gasification process greatly influence the syngas composition distribution. (iv) Higher values of the main components (especially $\mathrm{C}$ and $\mathrm{H}$ ) in the sewage sludge plant affect the increase of the LHV of gasification gas. (v) Throughout the range of analyzed air ratios $(\lambda=0.12-0.27)$ the volumetric fractions of the main combustible components of gasification gas ( $\mathrm{CO}$ and $\left.\mathrm{H}_{2}\right)$ are higher in the case of the SS1 (positive aspect) in comparison to SS2. (vi) Taking into consideration the lower heating value LHV of the gasification gas there is the optimum value of the air ratio equal to 0.18 in which the LHV takes its maximum value. It is true irrespective of the sewage sludge type. (vii) The yield of the main producer gas components, $\mathrm{CO}, \mathrm{H}_{2}$ and $\mathrm{CH}_{4}$, was enhanced by increasing the gasification agent temperature and increasing of the oxygen concentration in the gasification agent.

\section{Acknowledgments}

The paper has been prepared within the frame of the Grant no RGH-6/RIE6/2014.

\section{Conflicts of Interest}

The authors declare no conflict of interest.

\section{References}

1. Tolis, A.; Rentizelas, A.; Aravossis, K.; Tatsiopoulos, I. Electricity and combined heat and power from municipal solid waste; theoretically optimal investment decision time and emissions trading implications. Waste Manag. Res. 2010, 28, 985-995.

2. Cucchiella, F.; D'Adamo, I.; Gastaldi, M. Municipal waste management and recovery in an Italian region. Waste Manag. Res. 2012, 30, 1290-1298.

3. Sommer, M.; Ragossing, A. Energy from waste in Europe: An analysis and comparison of the EU27. Waste Manag. Res. 2011, 29, 69-77.

4. Basu, P. Biomass Gasification and Pyrolysis: Practical Design and Theory; Elsevier Academic Press: Waltham, MA, USA, 2010.

5. Basu, P. Combustion and Gasification in Fluidized Beds; Taylor \& Francis Group/CRC Press: Boca Raton, FL, USA, 2006.

6. Werle, S. Possibility of $\mathrm{NO}_{x}$ emission reduction from combustion process using sewage sludge gasification gas as an additional fuel. Arch. Environ. Prot. 2012, 38, 81-89. 
7. Seggiani, M.; Puccini, M.; Raggio, G.; Vitolo, S. Effect of sewage sludge content on gas quality and solid residues produced by cogasification in an updraft gasifier. Waste Manag. 2012, 32, 1826-1834.

8. Phuphuakrat, T.; Nipattumakul, N.; Namioka, T.; Kerdsuwan, S. Characterization of tar content in the syngas produced in a downdraft type fixed bed gasification system from dried sewage sludge. Fuel 2010, 89, 2278-2284.

9. Midilli, A.; Dogru, M.; Howarth, C.R.; Ling, M.J.; Ayhan, T. Combustible gas production from sewage sludge with a downdraft gasifier. Energy Convers. Manag. 2001, 42, 155-172.

10. Dogru, M.; Midilli, A.; Howarth, C.R. Gasification of sewage sludge using a throated downdraft gasifier and uncertainty analysis. Fuel Proc. Technol. 2002, 75, 55-82.

11. Werther, J.; Ogada, T.; Borodulya, V.A.; Dikalenko, V.I. Devolatization and Combustion Characteristics of Wet Sewage Sludge in a Bubbling Fluidized Bed Furnace. In Proceedings of the Institute of Energy Conference, London, UK, 4-5 December 1995; pp. 149-158.

12. Nilsson, S.; Gómez-Barea, A.; Cano, D.F. Gasification reactivity of char from dried sewage sludge in a fluidized bed. Fuel 2012, 92, 346-353.

13. Sharma, A.K. Experimental investigations on a $20 \mathrm{kWe}$, solid biomass gasification system. Biomass Bioenergy 2011, 35, 421-428.

14. E4Tech. Review of Technologies for Gasification of Biomass and Wastes. Available online: http://www.ecolateral.org/gasificationnnfc090609.pdf (accessed on 23 July 2015).

15. Wilk, R.K.; Werle, S. Biomass Gasification Installation, Mainly for Sewage Sludge. Poland Patent no P-397225, 2 December 2011.

16. Werle, S.; Wilk, R.K. Analysis of use a sewage sludge derived syngas in the gas industry. Rynek Energii 2011, 4, 23-27.

17. Solid Biofuels-Methods for Moisture Determining Using Drier Method. Part 3-Moisture Analysis in General Sample; Standards PN-EN 14774-3:2010; Polish Committee for Standardization: Warsaw, Poland, 2010.

18. Solid Recovered Fuels-Determination of Volatile Content; Standards PN-EN 15402:2011; Polish Committee for Standardization: Warsaw, Poland, 2011.

19. Solid Recovered Fuels-Determination of Ash Content; Standards PN-EN 15403:2011; Polish Committee for Standardization: Warsaw, Poland, 2011.

20. Tomza-Marciniak, A.; Witczak, A. Distribution of endocrine-disrupting pesticides in water and fish from the Oder River, Poland. Acta Ichthyol. Piscat. 2010, 40, 1-9.

21. Kim, J.-W.; Mun, T.-Y.; Kim, J.-O.; Kim, J.-S. Air gasification of mixed plastic wastes using a two-stage gasifier for the production of producer gas with low tar and high caloric value. Fuel 2011, 90, 2266-2272.

(C) 2015 by the authors; licensee MDPI, Basel, Switzerland. This article is an open access article distributed under the terms and conditions of the Creative Commons Attribution license (http://creativecommons.org/licenses/by/4.0/). 